\title{
DISEMINASI TEKNIS \\ PELAKSANAAN UU NO. 6 TAHUN 2014 TENTANG DESA \\ BAGI APARATUR PEMERINTAHAN DESA MUNDING KECAMATAN BERGAS KABUPATEN SEMARANG
}

\author{
Arif Hidayat $^{1}$ \\ Fakultas Hukum Universitas Negeri Semarang \\ email: arifardat@gmail.com
}

Key word:

Village Act, Village

Government,

Participation

\section{Abstract}

Village governance based on Law No. 6 of 2014 concerning the Village (Village Act) is needed by the village officials Munding Bergas District of Semarang Regency. This dissemination using interactive discussion techniques to strengthen their understanding of the technical implementation of the Law on the Village contained in various regulation Villages of Rural Development Year 2015. Lessons to be learned from this activity is that the consistency of rural development must be supported by the commitment, awareness and active participation all interested parties on the progress of the village, as a forum for the public welfare

\section{Kata Kunci \\ UU Desa, \\ Pemerintahan Desa, Partisipasi}

\begin{abstract}
Abstrak
Penyelenggaraan pemerintahan desa berdasarkan Undang-Undang Nomor 6 Tahun 2014 tentang Desa (UU Desa) sangat dibutuhkan oleh aparatur Desa Munding Kecamatan Bergas Kabupaten Semarang. Diseminasi ini menggunakan teknik diskusi interaktif untuk memperkuat pemahaman mereka terhadap teknis implementasi UU Desa yang tertuang dalam berbagai Peraturan Menteri Desa \& Pembangunan Daerah Tertinggal Tahun 2015. Pembelajaran yang dapat diambil dari kegiatan ini adalah bahwa konsistensi pengembangan desa harus didukung dengan komitmen, kesadaran serta partisipasi aktif seluruh pihak yang berkepentingan terhadap kemajuan desa, sebagai wadah untuk mewujudkan kesejahteraan masyarakat
\end{abstract}




\section{PENDAHULUAN}

Kegiatan pembangunan nasional dengan segala ukuran keberhasilan dan dampak positif serta negatifnya, tidak terlepas dari kerja keras dan pengabdian aparat pemerintah desa. Meskipun demikian, masih banyak masalah yang dihadapi masyarakat desa yang sampai saat ini belum dapat diatasi secara tuntas, seperti masalah pengangguran, kemiskinan, ketimpangan distribusi pendapatan, ketidakseimbangan struktural ataupun keterbelakangan pendidikan. Kenyataan ini telah membuktikan bahwa meskipun desa memiliki dua sumberdaya penting yaitu SDM dan SDA, tetapi kesatuan masyarakat hukum tersebut tidak mampu mengubah potensi yang dimilikinya menjadi sebuah kekuatan guna memenuhi kebutuhannya sendiri (Piliang, 2003: 11-13).

Bagir Manan, (2001: 41) menyebutkan bahwa pemerintah desa yang diberi kepercayaan masyarakat, tidak cukup mempunyai kewenangan untuk berbuat banyak. Kedudukan dan bentuk organisasinya yang mendua (ambivalen) yaitu antara bentuk organisasi pemerintah dengan lembaga kemasyarakatan, tidak adanya sumber pendapatan yang memadai, keterbatasan kewenangan dalam pengambilan keputusan yang menyangkut rumah tangganya, keterbatasan kualitas dan kuantitas personilnya, merupakan sebagian kendala yang menghambat kinerja pemerintah desa.

Keterbatasan

kemampuan pemerintah desa dalam menjalankan fungsi dan peranannya menyebabkan pertumbuhan dan perubahan sosial di desa berjalan lambat. Masyarakat desa cenderung pasif dalam melakukan perubahan sosial. Situasi ini menyebabkan masyarakat desa semakin tergantung pada pihak luar desa. Permasalahan yang tentunya menjadi hambatan dalam penyelenggaraan pemerintahan desa untuk mengemban misi mensejahterakan masyarakatnya. Pertimbangan kesejarahan dan adaptasi serta antisipasi terhadap berbagai tuntutan perkembangan, termasuk dalam penyelenggaraan pemerintahan, menjadi dasar pengembangan desa ke depan. Sejalan dengan hal tersebut, pemerintah telah memberikan landasan sebagai arah pengembangan desa di masa yang akan datang (Said, M. Mas'ud, 2005: 54).

Desa Munding yang didirikan oleh Syekh Ghozali dan istrinya Siti Maesaroh, merupakan salah satu desa di Kecamatan Bergas, Semarang, Jaw a Tengah. Wilayahnya terdiri dari 3 dusun, yaitu: Gemawang, Munding atau Krajan, 
dan Cemanggal. Sebagian besar penduduknya berprofesi sebagai petani, buruh pabrik dan pedagang. Hasil pertaniannya berupa bawang, daun bawang, padi, jagung, cabe serta beberapa buah-buahan. Topografi Munding berupa perbukitan Cemanggal merupakan dusun di Munding yang paling tinggi letak geografisnya. Potensi yang demikian beragam mulai dari suburnya wilayah, strategisnya posisi desa berbanding terbalik dengan tingkat pendapatan perkapita penduduknya, demikian pula pertanian sayur mayur juga sering dirugikan oleh tengkulak. Hal demikian memungkinkan pihak desa mempersiapkan diri dalam merancang dan menjalankan program desa sesuai dengan regulasi yang baru.

Penyelenggaraan Pemerintahan Desa yang demokratis hanya akan terjadi apabila didukung oleh pemerintahan desa yang baik dan sebaliknya pemerintahan yang baik akan diperkuat dengan Kelembagaan Kemasyarakatan Desa yang demokratis. Dengan demikian, terdapat hubungan timbal balik dan saling menunjang antara pemerintahan yang baik dengan Lembaga Kemasyarakatan Desa yang demokratis (Slamet Luwihono, 2005: 13).

Berdasarkan identifikasi latar masalah di atas maka dapat dirumuskan permasalahan mengenai peningkatan pemahaman aparatur pemerintahan desa dalam teknis implementasi UU No. 6 Tahun 2014 Tentang Desa di Desa Munding Kecamatan Bergas Kabupaten Semarang. Kegiatan ini diharapkan dapat memberikan implikasi positif dalam penataan lembaga kemasyarakatan desa yang partisipatif guna: (a) melindungi dan memperluas ruang otonomi dan kebebasan masyarakat, (b) membatasi kekuasaan (kewenangan dan intervensi) pemerintah daerah dan pusat, serta melindungi hak-hak prakarsa masyarakat desa, (c) menjamin kekebasan masyarakat desa, (d) melindungi dan membela kelompok yang lemah di desa, (e) menjamin partisipasi dalam proses pengambilan keputusan antara lain, dengan memastikan bahwa masyarakat desa terwakili kepentingannya dalam BPD, dan (f) memfasilitasi perbaikan dan pengembangan kondisi sosial politik-ekonomi masyarakat desa. Untuk itu maka menjadi perlu dimilikinya kemampuan dan pemahaman komperhensif mengenai teknis pelaksanaan UU Desa.

\section{METODE}

Metode yang dipergunakan dalam pelatihan ini adalah diskusi terarah dengan masyarakat terpilih, diskusi ini diikuti oleh 
semua pihak yang terkait. Dalam kegiatan ini akan ditentukan lebih lanjut mengenai pihak-pihak yang akan dilibatkan, adapun pemilihan tempat dan lokasi disesuaikan dengan kebutuhan dan kekritisan daerah yang terkena dampak baik secara langsung maupun tidak langsung, pemilihan tempat berdasarkan wilayah yang belum mendapatkan sosialisasi sama sekali, yaitu di Desa Munding. Khalayak sasaran dalam kegiatan pengabdian ini adalah: Tokoh masyarakat; Tokoh Pemuda; Lembaga Masyaakat Desa (LMD); Badan Permusyawaratan Desa (BPD) dan Aparatur pemerintah setempat. Kegiatan pelatihan diselenggarakan pada hari Minggu, 8 November 2015, bertempat di Kantor Desa Munding, Kecamatan Bergas Kabupaten Semarang, diikutioleh 18 orang yang terdiri dari unsur tokoh

masyarakat dan tokoh pemuda, LMD dan BPD serta perangkat desa.

\section{HASIL DAN PEMBAHASAN}

Kegiatan ini telah dilakukan dalam 4 (empat) tahapan, yaitu: Tahap observasi, Tahap persiapan (Perijinan), Tahap Pelaksanaan, dan Tahap Evaluasi (RTL). Hasil yang telah dicapai adalah tahap observasi dan persiapan. Pelaksanaan pengabdian direalisasikan melalui berbagai rangkaian kegiatan, diawali dengan kajian dan observasi yang dilakukan secara terstruktur, baik langsung maupun tidak langsung. Tahap kajian dan observasi dilakukan pada tanggal 27-28 Agustus 2015 dan tanggal 2 September 2015. Kajian dan observasi ini menghasilkan identifikasi dan klasifikasi internal maupun eksternal berdasarkan analisis SWOT, antara lain dalam tabel berikut.

Tabel 1

Identifikasi \& Klasifikasi Faktor Internal-Eksternal

\section{FAKTOR INTERNAL}

\begin{tabular}{|l|l|}
\hline A. Kekuatan (Strenghts) & B. Kelemahan (Weaknesses) \\
\hline *Jumlah penduduk yang cukup besar & * Kualitas Sumber Daya Aparatur \\
merupakan potensi SDM. & Pemerintah Desa umumnya masih \\
* Mayoritas penduduk di pedesaan & rendah. \\
berusia produktif. & *Terdapatnya tumpang tindih pelaksanaan \\
*Stabilitas keamanan yang cukup & tugas-tugas pemerintahan dan pelayanan \\
kondusif. & umum di desa. \\
* Laju pertumbuhan ekonomi yang & * Belum lengkapnya aturan pelaksanaan \\
positif melalui pengembangan & tentang desa sebagai pedoman maupun \\
agribisnis. & landasan operasional penyelenggaraan \\
*Terdapatnya potensi SDA yang dapat & pemerintahan desa. \\
mendukung percepatan dinamika & * Belum maksimalnya pemasaran produk- \\
perekonomian desa dan daerah. & produk unggulan lokal karena \\
\hline
\end{tabular}




\begin{tabular}{|c|c|}
\hline $\begin{array}{l}\text { * Terdapatnya komoditas unggulan } \\
\text { seperti Salak dan Bunga Potong yang } \\
\text { tersebar merata di hampir seluruh desa. }\end{array}$ & $\begin{array}{l}\text { keterbatasan akses pada pasar serta } \\
\text { minimnya kemampuan manajemen } \\
\text { pemasaran di perdesaan. } \\
\text { * Rendahnya kemampuan perencanaan di } \\
\text { tingkat desa. }\end{array}$ \\
\hline \multicolumn{2}{|c|}{ FAKTOR EKSTERNAL } \\
\hline C. Pelu & D. Ancaman (Threats) \\
\hline $\begin{array}{l}\text { * Adanya pemberian bagian dari Dana } \\
\text { Perimbangan Kabupaten yang } \\
\text { memperkuat aspek keuangan desa. } \\
\text { * Pembinaan dan pengawasan dari } \\
\text { kecamatan dan kabupaten (pemerintah } \\
\text { supradesa) yang dilakukan secara } \\
\text { konsisten dan berkesinambungan. } \\
\text { * Pengembangan ekonomi dan kawasan } \\
\text { perdagangan di wilayah Bergas. } \\
\text { * Pengembangan pemanfaatan IPTEK } \\
\text { dan TTG dalam usaha ekonomi } \\
\text { perdesaan yang dapat dilakukan } \\
\text { melalui berbagai upaya seperti melalui } \\
\text { kerjasama secara saling } \\
\text { menguntungkan dengan lembaga } \\
\text { penelitian atau perguruan tinggi. } \\
\text { * Adanya praktek-praktek lapangan } \\
\text { mahasiswa dari berbagai perguruan } \\
\text { tinggi di Jawa Tengah yang ikut } \\
\text { mendorong peningkatan administrasi } \\
\text { pemerintahan desa, pembangunan, dan } \\
\text { kemasyarakatan. }\end{array}$ & $\begin{array}{l}\text { * Tingginya kepemilikan tanah oleh pihak } \\
\text { dari luar yang berdampak pada } \\
\text { lambatnya proses pelunasan PBB di } \\
\text { beberapa dusun. } \\
\text { * Terbatasnya alokasi dana/anggaran, yang } \\
\text { berakibat terbatasnya operasional } \\
\text { program/kegiatan. } \\
\text { * Sarana dan prasarana penunjang } \\
\text { operasional yang masih terbatas. } \\
\text { * Masih lemahnya koordinasi antar sektor, } \\
\text { yang diakibatkan belum mantapnya } \\
\text { persepsi terhadap substansi serta } \\
\text { kurangnya dukungan mekanisme } \\
\text { peraturan tentang pengembangan } \\
\text { otonomi desa, dan adanya kecenderungan } \\
\text { arogansi sektoral dalam pelaksanaan } \\
\text { pembangunan pedesaan. } \\
\text { * Pemberlakuan kebijakan tentang } \\
\text { pengangkatan sekdes menjadi PNS dan } \\
\text { penggantian perangkat desa yang tidak } \\
\text { lagi memenuhi persyaratan merupakan } \\
\text { permasalahan yang dapat menimbulkan } \\
\text { konflik. }\end{array}$ \\
\hline
\end{tabular}

Tahap persiapan, diawali dengan proses pemberitahuan lisan kepada Kepala Desa Munding pada tanggal 1 November 2015, dilanjutkan pengurusan pengurusan ijin tertulis dari FH UNNES. Tanggapan positif diberikan, bahkan Kepala Desa Munding, Ibu Dani antusias dalam menerima tim pengabdian mengingat materi mengenai pelatihan sangat dibutuhkan oleh pemerintahan desa.
Tahap pelaksanaan, meliputi 2 (dua) tahap kegiatan, yaitu brainstorming dan diseminasi (diskusi terarah). Brainstorming dilakukan pada hari Jumat, tanggal 6 November 2015. Tim Pengabdian melakukan koordinasi dengan pihak Desa, baik mengenai materi, peserta sekaligus personil yang dipersiapkan serta waktu pelaksanaan agar pelaksanaan pengabdian tersebut efektif dan efisien, relevan dan 
tepat sasaran. Tahap ini diikuti dengan prepare oleh Tim Pengabdian dengan mempersiapkan segala perangkat maupun kebutuhan untuk pelaksanaan kegiatan.

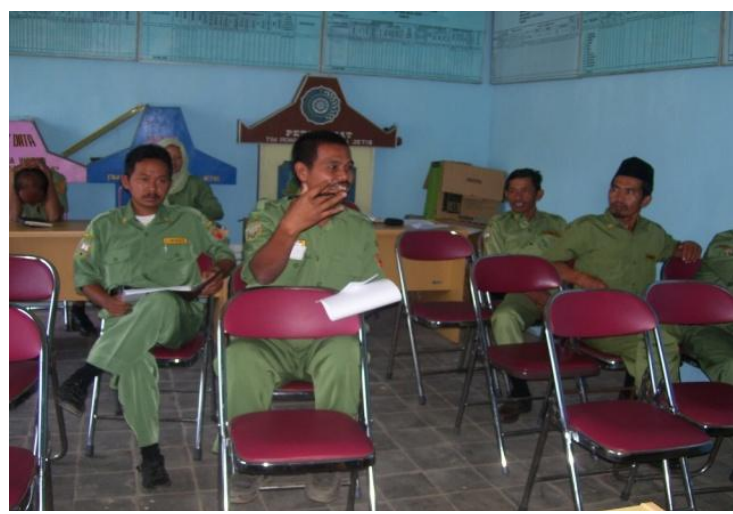

Gambar1. Brainstorming dengan perangkat Desa Munding

Sedangkan realisasi kegiatan penyuluhan dilaksanakan pada hari Minggu, 8 November 2015, di ruang Pertemuan Desa Munding diikuti 18 orang yang terdiri dari unsur tokoh masyarakat dan tokoh pemuda, LMD dan BPD serta perangkat desa. Diseminasi dilakukan melalui diskusi terfokus yang terbagi ke dalam 2 (dua) sesi, yaitu: (1) Sosialisasi, berisi penjelasan materi pokok UU No. 6 Tahun 2014 Tentang Desa oleh Dr. Sutrisno, PHM., M.Hum; dan (2) Dialog Interaktif untuk memperkuat pemahaman tentang materi pokok UU No. 6 Tahun 2014 Tentang Desa dipandu oleh Arif Hidayat.

Pelaksanaan penyuluhan dimulai dengan pengantar diskusi, yaitu menyampaikan materi pada tiap sesi dengan menggunakan media sederhana berupa kertas plano dan white board serta
LCD, kemudian dilanjutkan diskusi terarah. Selama pelatihan berlangsung banyak peserta yang ingin menyampaikan gagasan maupun pertanyaan, akan tetapi mengingat waktu yang terbatas, tidak semua pertanyaan dapat terjawab dan dirumuskan dalam diskusi tersebut.

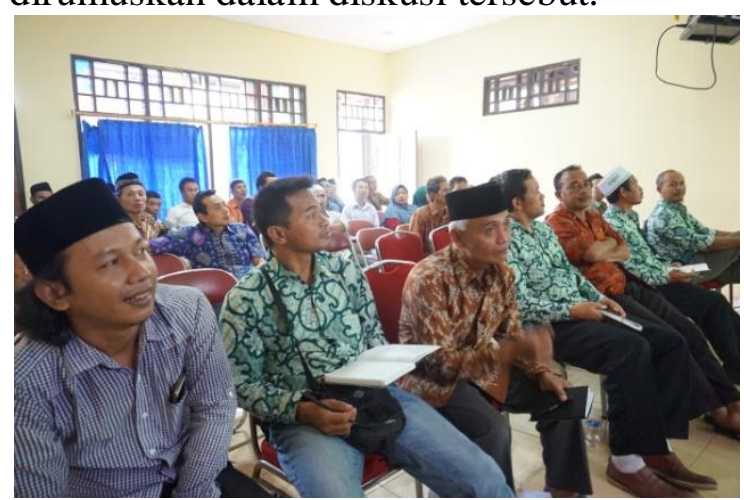

Gambar 2. Diseminasi dan Pemaparan UU No 6 tahun 2014

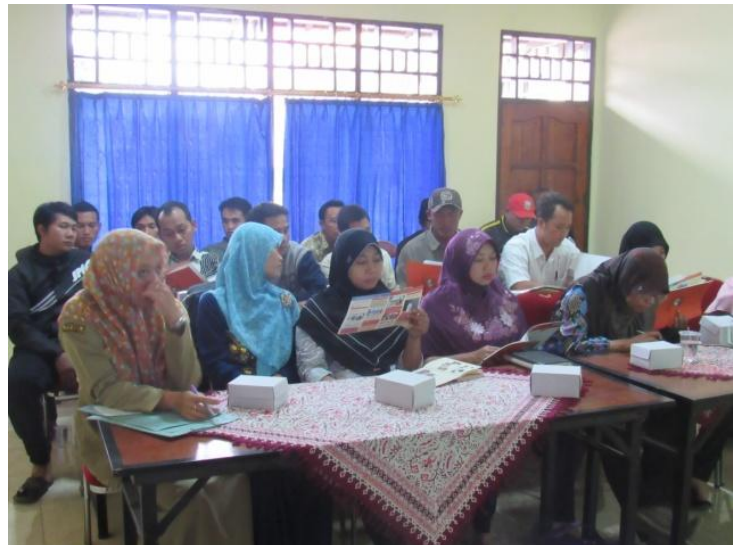

Gambar 3. Diseminasi dan Pemaparan UU No 6 tahun 2014

Dari sekian gagasan dan tanya jawab yang terrekam menunjukkan bahwa dalam rangka pelaksanaan UU No. 6 Tahun 2014, para stakeholders pemerintahan desa dan tokoh masyarakat tersebut belum memahami secara komprehensif mengenai pokok-pokok materi dalam UU No. 6 Tahun 2014 beserta perangkat pelaksanaannya, berkaitan dengan 
Kedudukan dan Jenis Desa; Penataan

Desa; Kewenangan Desa; Penyelenggaraan

Pemerintahan Desa; Hak dan Kewajiban

Desa dan Masyarakat Desa; Keuangan

Desa dan Aset Desa; serta Pembangunan

Desa dan Pembangunan Kawasan Perdesaan.

Adapun muatan yang terkandung didalamnya adalah:

1. Aspek Hukum dan Kebijakan yang mendorong penataan lembaga kemasyarakatan desa dalam sistem pembangunan tata pemerintahan yang berkelanjutan;

2. Aspek peningkatan partisipasi kelembagaan masyarakat dalam pengambilan keputusan kebijakan pemerintah desa;

3. Aspek kelembagaan, koordinasi dan kemitraan antar kelompok masyarakat melalui penataan lembaga kemasyarakatan desa demi peningkatkan aksesibilitas masyarakat terhadap inovasi teknologi, perkreditan, sarana produksi, maupun informasi pasar;

4. Aspek dukungan infrastruktur pendukung dari sektor non pertanian (pasar, irigasi, jalan, listrik, dll)

Kegiatan ini menggunakan instrumen pre test berupa Angket (Pre-Question) untuk menilai kemampuan peserta diskusi terarah sebelum dilaksanakan penyuluhan. Hasil pre test menunjukkan bahwa peserta pelatihan sama sekali tidak memahami pengaturan (regulasi) mengenai penataan lembaga kemasyarakatan desa. Bahkan, peserta pelatihan belum terlibat secara aktif dalam lembaga kemasyarakatan desa.

Secara umum hasil kegiatan penyuluhan ini menunjukkan hasil positif, mengingat partisipasi aktif, keseriusan dan antusiasme peserta. Dukungan penuh dari Ketua LP2M UNNES dan Dekan FH UNNES maupun Kepala Desa Munding Kecamatan Bergas, mempermudah terlaksananya kegiatan pengabdian, sehingga tidak ada hambatan mendasar yang dihadapi, selain keterbatasan waktu dan media yang dibutuhkan.

Beberapa faktor yang mendukung keberhasilan pelaksanaan pengabdian ini. Secara teknis, materi dan metode penyuluhan tepat efektif dan sasaran, karena peserta yang mengikuti kegiatan betul-betul menginginkan pemahaman mengenai materi yang diberikan. Sedangkan secara non teknis, strategi pembangunan desa melalui penataan lembaga kemasyarakatan sangat dibutuhkan. 


\section{PENUTUP}

\section{SIMPULAN}

Berdasarkan hasil evaluasi, pengamatan dan tanggapan langsung dari peserta penyuluhan, kegiatan pengabdian ini cukup berhasil mengingat adanya peningkatan pemahaman mengenai pokokpokok materi dalam UU No. 6 Tahun 2014 beserta perangkat pelaksanaannya. Hal ini dibuktikan dengan kemampuan mereka menyikapi berbagai persoalan pembangunan di Desa Munding Bergas Kabupaten Semarang, dalam post test yang dilaksanakan pada akhir kegiatan. Pembelajaran yang dapat diambil dari kegiatan ini adalah bahwa konsistensi pengembangan desa harus didukung dengan komitmen, kesadaran serta partisipasi aktif seluruh pihak yang berkepentingan terhadap kemajuan desa, sebagai wadah untuk mewujudkan kesejahteraan masyarakat. Secara umum, keberhasilan pengembangan desa akan sangat tergantung kepada kemampuan aparatur pemerintah supradesa dan pemerintah desa, serta segenap komponen (stakeholders) yang terkait dalam penyelenggaraan pemerintahan desa, dalam memahami dan memanfaatkan berbagai potensi yang dimiliki. Secara khusus, tingkat keberhasilan pencapaian target (kualitatif dan kuantitatif) yang ditetapkan, lebih banyak tergantung pada input dari berbagai aspek untuk pengembangan otonomi desa.

\section{SARAN}

Berdasarkan responsi peserta penyuluhan terhadap permasalahan yang dihadapi Desa Munding Bergas Kabupaten Semarang, tim pengabdian merekomendasikan bahwa dalam rangka menghadapi dinamika dan tantangan otonomi desa ke depan, perlu kiranya ada suatu kebijakan umum pengembangan otonomi desa sebagai salah satu upaya untuk lebih mengarahkan dan mengoptimalkan pelaksanaan pembangunan desa secara komprehensif, terpadu dan terkoordinasi dalam rangka pencapaian tujuan secara efektif dan efisien untuk menciptakan kesejahteraan masyarakat.

\section{DAFTAR PUSTAKA}

Manan, Bagir, 2001 Menyongsong Fajar Otonomi Daerah, Yogyakarta: Penerbit Pusat Studi Hukum Fakultas Hukum UII Yogyakarta

Piliang, Indra J. dkk (editor), 2003. Otonomi Daerah: Evaluasi dan Proyeksi, Jakarta: Yayasan Harkat Bangsa

Said, M. Mas'ud, 2005. Arah Baru Otonomi Daerah di Indonesia, Malang: UMM Press 
Sarundajang, 2003. Arus Balik Kekuasaan Pusat ke Daerah, Jakarta: Sinar Harapan

Slamet Luwihono, "Renstra (RENSTRA): Instrumen Menggapai kesejahteraan Masyarakat di Era Transisi Otonomi Daerah", dalam Majalah Tetruka, Edisi Januari 2005 